\title{
Chemiluminescent microparticle immunoassay based detection and prevalence of HCV infection in district Peshawar Pakistan
}

\author{
Muhammad llyas ${ }^{1}$ and Irshad Ahmad ${ }^{2^{*}}$
}

\begin{abstract}
Background: Due to the high rate of asymptomatic infections an advanced screening assay is of prompt importance to be used for the clinical diagnosis of HCV. Early detection of anti HCV is the first step in the management of chronic hepatitis and in the selection of patients needing treatments. In the current study we have first time used the advanced serological diagnostic technique i.e. Chemiluminescent Microparticle Immuno Assay (CMIA) for the detection of HCV infection in Peshawar Pakistan.
\end{abstract}

Methods: A total number of 982 samples were collected among the general public belongs to the different areas of district Peshawar. The samples were centrifuged at high speed to obtain a clear supernatant serum. All the samples were run on Architect system a fully automated immuno analyzer CMIA base technology.

Results: Out of 982 blood samples analyzed in this study, 160 (15.9\%) were confirmed to be positive for active HCV infection. The overall prevalence was found to be $13.4 \%$. Gender wise prevalence was recorded to be higher in male (19.1\%) than female (12.7\%). The age group 21-30 years was identified as the highest risk group among the studied population.

Conclusion: Among the tested samples, overall prevalence of active HCV infection was found to be $13.4 \%$ in the general population of Peshawar Pakistan. The young middle aged population of this region was at higher risk of HCV ailments compared to the other age groups.

Keywords: HCV, CMIA, Prevalence

\section{Background}

Hepatitis $C$ is a viral infectious disease of liver. At early stages the infection is asymptomatic but once established, it can progress to advanced liver diseases such as liver fibrosis and ultimately cirrhosis. These liver diseases can further lead to other complications such as liver failure and liver cancer [1]. HCV is a plus-stranded RNA virus and is a distinct member of the familyFlaviviridae. HCV has infected about 200 million people worldwide which are about $3.3 \%$ of the world population [2]. Approximately $20-30 \%$ of patients naturally clear the virus. About $70-80 \%$ acute HCV infections become chronic that leads to the development of cirrhosis in $20 \%$ of cases while the same

\footnotetext{
* Correspondence: adenzai_ia@yahoo.com

${ }^{2}$ Biology Department, King Fahd University of Petroleum and Minerals (KFUPM), 34464 Dhahran, Saudi Arabia

Full list of author information is available at the end of the article
}

percentage of patients becomes victim of hepatocellular carcinoma. Acute hepatitis $\mathrm{C}$ occurs during the first six months of HCV infection [3].

Prevalence of $\mathrm{HCV}$ varies throughout the world. Liver cirrhosis is a major cause of mortality and HCV related liver cancer is the $8^{\text {th }}$ common cancer worldwide $[4,5]$. In Pakistan, more than 10 million people are suffering from $\mathrm{HCV}$ that comprise $6 \%$ of total population, with high morbidity and mortality [6]. In previous studies high $\mathrm{HCV}$ prevalence was reported in other cities of Pakistan. There were 16\% in Lahore, 20.6\% in Faisalabad and $23.8 \%$ in Gujranwala [7] but no such report is there as far as Peshawar region is concerned.

Due to high rate of asymptomatic infections, an advanced screening assay is of prompt importance to be used for the clinical diagnosis of $\mathrm{HCV}$. Early anti $\mathrm{HCV}$ detection is the first step in the management of chronic hepatitis in order 
to select the patients for timely treatment [8]. Various methods are implemented for the diagnosis of hepatitis infection i.e. Immune Chromatographic Technique (ICT), Enzyme Linked Immuno Sorrbant Assay (ELISA) and HCV-RNA by PCR, but due to the false positivity rate of $\mathrm{HCV}$ with ICT based methods, ELISA is considered to be more consistent than ICT based HCV diagnosis [9]. The detection of HCV RNA by PCR is more reliable; however, PCR assay is costly, has technical hitches and it needs skilled personnel for the operation and interpretation of the output. Patients in this region with low socioeconomic status will not be able to afford it. The current study we have focused on, the Chemiluminescent Microparticle Immuno Assay (CMIA), an advanced serological diagnostic technique, provides a rapid, cost-effective and reliable way to detect $\mathrm{HCV}$, and therefore, is the method that was implemented for the diagnosis of hepatitis infection.

\section{Results and discussion}

A total of 982 blood samples were collected from the district Peshawar Pakistan and were screened for anti HCV. The current study was carried out during February, 2013-14. Among 982 samples 127 were detected as HCV positive. Figure 1 shows a prevalence of $\mathrm{HCV}$ positive samples in different age groups with respect to male/ female population. As shown in Table 1, the gender-wise prevalence of active $\mathrm{HCV}$ infection was estimated to be $15.4 \%$ in male (84 positive out of 543 samples) and $9.7 \%$ in female subjects (43 positive out of 439 samples) respectively. Considering the age group criterion, significant differences were observed in the prevalence of HCV in both genders. The highest prevalence of $18.5 \%$ was observed in age group 21-30 ( $p=0.9407$, OR $=0.972,95 \%$ $\mathrm{CI}=0.470-2.014)$, however statistically significant active $\mathrm{HCV}$ infection was noted in age group 31-40 with a prevalence of $17.2 \%$ ( $p=0.0007, \mathrm{OR}=4.626,95 \% \mathrm{CI}=$ $1.802-11.88)$. Both of these values are higher compared to the age group 11-20 years having a prevalence of $3.7 \%$
( $p=0.5889, \mathrm{OR}=0.607,95 \% \mathrm{CI}=0.098-3.761)$. The age groups of 41-50 and $>50$ was associated with a decrease trend of active $\mathrm{HCV}$ prevalence of $13.1 \%(\mathrm{p}=0.1757$, $\mathrm{OR}=1.803,95 \% \mathrm{CI}=0.761-4.268)$ and $14.6 \%(p=0.2740$, $\mathrm{OR}=1.595,95 \% \mathrm{CI}=0.687-3.701)$ respectively.

Previous reports on $\mathrm{HCV}$ prevalence in other regions of Khyber Pakhtunkhwa, Pakistan were shown in Table 2. A high prevalence of $\mathrm{HCV}$ (57\% and 36\%) was observed among the thalassaemic patients $[10,11]$. Others regions like Mardan, Risalpur, Peshawar, Abbottabad and Bunner showed HCV prevalence as 3.69\%, 3.40\%, 2.20\%, $8 \%$ and $4.57 \%$ respectively.

Hepatitis $\mathrm{C}$ virus (HCV) is a major cause of liver disease and has a high potential to cause significant morbidity and mortality worldwide [17]. Prevalence of HCV in Pakistan is the highest in the world and estimated to be $4.8 \%$ [18]. Currently, about 10 million people are infected with $\mathrm{HCV}$ in Pakistan [19]. The prevalence of hepatitis $C$ varies in different provinces of Pakistan. It was found to be high in Sind and Punjab that is $5-6 \%$ [20]. The present study was conducted during February, 2013-14 in order to find out the prevalence of $\mathrm{HCV}$ among the general public of district Peshawar, Pakistan.

We have found the overall prevalence of HCV as $13.4 \%$ which is higher than $4.9 \%$ previously reported among the general public of Lahore, Pakistan [1]. This major difference among the overall prevalence may be due to using of different diagnostic techniques in the laboratories, immunological status of the persons and lack of awareness regarding hepatitis $\mathrm{C}$ virus particularly in district Peshawar Pakistan. Another study conducted among the healthy donors in Bolichistan Pakistan reported 20.8\% prevalence which was slightly higher than our present study [21]. This is due to the lack of education, poverty and unhygienic health status of the people in the region.

In the current study the incidence of $\mathrm{HCV}$ was higher in the age group 21-30 years i.e. 18.5\% which is in accordance with the previously reported results [21]. High prevalence

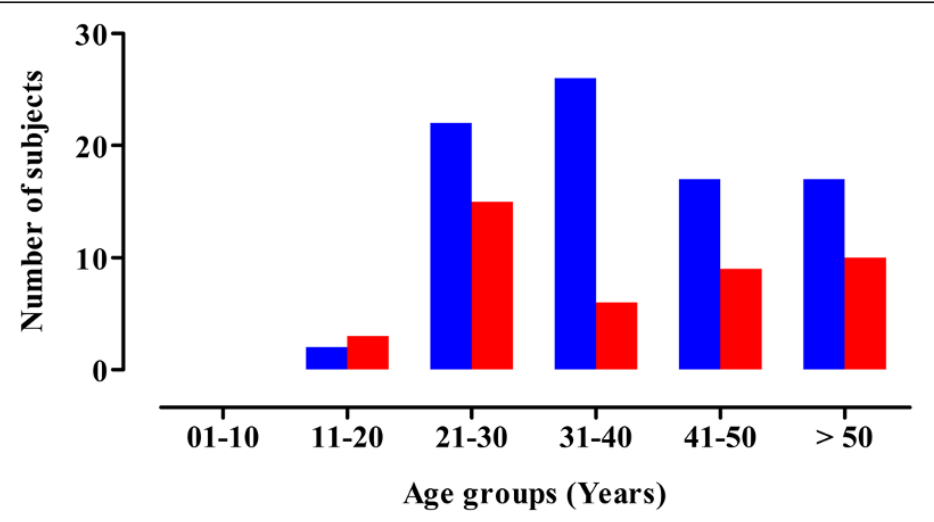

Figure 1 Prevalence of HCV positive samples in different age groups with respect to male/female population. 
Table 1 Frequency of HCV positive samples among different age groups and overall prevalence

\begin{tabular}{cccccccc}
\hline Age groups (years) & Sample size & Male $+/-$ & Female $+/-$ & $\boldsymbol{p}$ value & Odds ratio & Confidence interval & Overall prevalence (\%) \\
\hline $01-10$ & 80 & $00 / 50$ & $00 / 30$ & - & - & - & - \\
$11-20$ & 135 & $02 / 68$ & $03 / 62$ & 0.5889 & 0.607 & $0.098-3.761$ & 3.7 \\
$21-30$ & 200 & $22 / 98$ & $15 / 65$ & 0.9407 & 0.972 & $0.470-2.014$ & 18.5 \\
$31-40$ & 185 & $26 / 74$ & $06 / 79$ & $0.0007^{* * *}$ & 4.626 & $1.802-11.88$ & 17.2 \\
$41-50$ & 198 & $17 / 88$ & $09 / 84$ & 0.1757 & 1.803 & $0.761-4.268$ & 13.1 \\
$>50$ & 184 & $17 / 81$ & $10 / 76$ & 0.2740 & 1.595 & $0.687-3.701$ & 14.6 \\
\hline Total & $\mathbf{9 8 2}$ & $\mathbf{8 4 / 4 5 9}$ & $\mathbf{4 3 / 3 9 6}$ & - & - & - & $\mathbf{1 3 . 4}$ \\
\hline
\end{tabular}

Chi-square test was applied and $p<0.05$ was considered as significant at $95 \%$ confidence interval.

${ }^{* * *} p=$ value is significant.

of HCV was reported to be $49.01 \%$ among the age group 21-25 years pregnant women in Sindh [22], which were higher than our present study, but the overall prevalence of hepatitis $C$ virus was found to be as higher in the middle age group of the population in both studies.

The most terrible condition which we have observed in this study is the high prevalence of $\mathrm{HCV}$ in the young and middle aged people i.e. 21-30 and 31-40 years old respectively. A number of studies conducted on the prevalence of Hepatitis $\mathrm{C}$ virus in different areas of Pakistan $[1,21]$ showed high incidence of Hepatitis $C$ virus prevailed in these age groups. The occurrence of hepatitis among these age groups are contributed by lack of awareness, used of unsterile syringes, repeated use of razors and contaminated scissors for different customers without prior sterilization. It was observed that about $90 \%$ of barbers did not washed hands, $80 \%$ did not changed aprons and 66\% did not changed towels after each customer [23].

Another bad practice which made the environments worse is the recycling of used syringes. A very young scavenger of waste products around 18 to 20 years of age sells $20-25$ syringes per day to the health care waste dealers against money and the same child gets needle stick injury around none to three times per week [24].

The occurrence of hepatitis $\mathrm{C}$ virus found in the age group $>50$ years was $14.6 \%$ in the current study which is in accordance with the previously reported data [25].

Table 2 HCV prevalence in other regions of Khyber Pakhtunkhwa Pakistan

\begin{tabular}{ccccc}
\hline Region & Method & Population size & HCV prevalence & Reference \\
\hline Mardan & ELISA & 15550 & $3.69 \%$ & {$[12]$} \\
Risalpur & ELISA & 2558 & $3.40 \%$ & {$[13]$} \\
Peshawar & MEIA & 3430 & $2.20 \%$ & {$[14]$} \\
Abbotabad & ELISA & 102 & $8 \%$ & {$[15]$} \\
Bunner & ELISA & 16400 & $4.57 \%$ & {$[16]$} \\
Peshawar & ELISA & 80 & $36 \%$ & {$[11]$} \\
NWFP(KPK) & ELISA & 250 & $57 \%$ & {$[10]$} \\
\hline
\end{tabular}

The overall prevalence of active HCV among different aged groups reported in KPK, Pakistan was $7 \%$ by using ICT techniques [26] was much lower than our present study (13.4\%). This disagreement is due to small sample size in the former study and unreliable serological diagnostic techniques (ICT) used having low specificity and sensitivity.

The frequent methods used for the diagnosis of $\mathrm{HCV}$ infection based on the detection of anti $\mathrm{HCV}$ antibodies in the serum or plasma, but nevertheless the concentration of these antibodies reaches to detectable level after a long window period of $\mathrm{HCV}$ infection. Additionally viruses eliminating from the blood but still their presence in the serum or plasma for a long period of time could not differentiate between current and past $\mathrm{HCV}$ infection. At the same time methods used like ELISA and CMIA for detection of anti HCV antibodies gives false positive results. These false positive results for anti HCV are likely in population having low HCV prevalence due to some cross reactivity of others viral antigen and antibodies in individual have immune disorder [27-29]. According to the CDC all the screening methods used for the detection of anti $\mathrm{HCV}$ need supplementary methods like $\mathrm{HCV}$ RNA or nucleic acid testing (NAT) for their further confirmation. In the current study the detection of anti $\mathrm{HCV}$ antibodies by CMIA techniques have some disadvantages of giving false positive results, therefore further tests like NAT to detect HCV RNA is needed. However in spite of these recommendations supplementary tests are not performed in many laboratories due to some reasons which include technical complexity of the methods, high cost, long procedures. In such condition the guidelines set issued by $\mathrm{CDC}$ recommendations including option to use a signal to cutoff ratios to limit the number of the samples needing supplemental testing. According to CDC guidelines [30] the FDA approved anti HCV screening kits (ELISA, CMIA and RIBA) establishes specific signals to cutoff ratio which is $\mathrm{S} / \mathrm{CO} \geq 5.0$ for chemiluminescent immunoassay by architect system from Abbott diagnostic services which predicted a true antibodies positive 
results $>95 \%$ of the time. In the present study positive results for the tested samples were obtained where serum index $(\mathrm{S} / \mathrm{CO} \geq 5.0)$.

In the present study anti $\mathrm{HCV}$ detection was done by using a very sensitive and more advance diagnostic technique CMIA on the stat of the art Architect system which is a fully automated immuno analyzer of Abbott diagnostic services.

\section{Conclusions}

In this study we have used the most reliable, sensitive and advanced serological diagnostic technique for the detection of HCV antibodies in serum of infected persons. Among the tested samples, overall prevalence of active HCV infection was found to be $13.4 \%$ in the general population of Peshawar Pakistan. The HCV infection prevailed among all age groups but young middle age population of this region was at higher risk of $\mathrm{HCV}$ ailments compared to the other age groups. This study will be helpful to the health care policy makers to design strategies for controlling and eradication of Hepatitis $\mathrm{C}$ infection in Peshawar, Pakistan.

\section{Methods}

\section{Sample collection}

A total number of 982 sample were collected among the general public belongs to different areas of district Peshawar Pakistan. About $3 \mathrm{cc}$ blood is collected from each individual in gel vaccutainer tube. The relevant demography of the persons was recorded in separate forms. The age groups included in this study was $01-80$ years.

\section{Sample processing}

The samples were centrifuged at high speed about $8000 \mathrm{rpm}$ for 15 minutes in order to obtain a clear supernatant serum. All the samples were run on Architect system which is fully automated immuno analyzer of the Abbott diagnostic services.

\section{Chemiluminescent Microparticle Immuno Assay (CMIA)}

Chemiluminescent Microparticle Immuno Assay is the modified and advanced form of the Enzyme Linked Immuno Sorrbant Assay (ELISA) technique. Architect system is designed to detect antibodies to putative structural and non structural protein $(\mathrm{HCr}-43, \mathrm{c}-100, \mathrm{NS} 3$, NS4) of HCV genome [31]. In the final reaction of Anti $\mathrm{HCV}$ detection, bound achridinylated conjugates were used to generate chemiluminescent signals. Results were obtained automatically by the software by comparing the chemiluminescent signals obtained from the reaction product of the sample with the signal of the cutoff value previously obtained by Anti HCV calibration. The overall specificity and sensitivity of this method is $99.6 \%$ and $99.7 \%$ respectively.

\section{Statistical analysis}

Data was analyzed statistically by using GraphPad Prism 5 (GraphPad Software Inc. San Diego CA, USA). The Chi-square test was used to analyze the qualitative data. A $p$ value $<0.05$ was considered as significant. Odds ratio with $95 \%$ confidence interval was used to evaluate the association of various age groups with respect to $\mathrm{HCV}$ status of male/female population.

\section{Competing interests}

The authors declare that they have no competing interests.

\section{Authors' contributions}

$\mathrm{Ml}$ carried out samples collection and has participated in the experimental work. IA designed the overall study and prepared the manuscript. Both authors edited and approved the final manuscript.

\section{Acknowledgments}

The authors highly acknowledge the procession of lab facilities by City Medical Laboratory, Department of Microbiology and Biotechnology (SUIT), Peshawar, Pakistan and Biology Department, King Fahd University of Petroleum and Minerals (KFUPM), Dhahran, Kingdom of Saudi Arabia for the conduction of this study.

\section{Author details}

'Department of Microbiology and Biotechnology, Sarhad University of Science and Information Technology (SUIT), 25120 Peshawar, Pakistan. ${ }^{2}$ Biology Department, King Fahd University of Petroleum and Minerals (KFUPM), 34464 Dhahran, Saudi Arabia.

Received: 19 March 2014 Accepted: 8 July 2014

Published: 12 July 2014

\section{References}

1. Anwar MI, Rehman M, Hassan, Iqbal M: Prevalence of active hepatitis C Virus infections among general public of Lahore, Pakistan. Virol J 2013, 10:351.

2. Waheed Y, Shafi T, Safi SZ, Qadri I: Hepatitis C virus in Pakistan: A systematic review of prevalence, genotypes and risk factors. World J Gastroenterol 2009, 15(45):5647-5653.

3. Czepiel J, Biesiada G, Mach T: Viral hepatitis C. Pol Arch Med Wewn 2008, 118:734-740.

4. Umar M, Bilal M: Hepatitis C, a mega menace: a Pakistani Perspective. J Pioneer Med Sci 2012, 2(2):68-72.

5. Lavanchy D: The global burden of hepatitis C. Liver Int 2009, 29(suppl 1):74-81

6. Idrees $M$, Riazuddin S: Frequency distribution of hepatitis $C$ virus genotypes in different geographical regions of Pakistan and their possible routes of transmission. BMC Infect Dis 2008, 8:6.

7. Ahmad N, Asgher M, Shafique M, Qureshi JA: An evidence of high Seroprevalence of the antibody to hepatitis $C$ in select groups in the Punjab region of Pakistan. J Clin Gastroenterol 2001, 33:407-411.

8. Strader DB, Wright T, Thomas DL, Seeff LB: Diagnosis, Management and treatment of hepatitis C. Hepatology 2004, 39(4):1147-1171.

9. Afridi S, Naeem M, Hussain A, Kakar N, Babar ME, Ahmad J: Prevalence of hepatitis C virus (HCV) genotypes in Balochistan. Mol Biol Rep 2009, 36(6):1511-1514

10. Shah SMA, Khan MT, Zahour U, Ashfaq NY: Prevalence of hepatitis B and hepatitis $C$ virus infection in multi transfused thalassaemia major patients in North West Frontier Province. Pak J Med Sci 2005, 21:281-284.

11. Muhammad J, Hussain M, Khan MA: Frequency of Hepatitis B and Hepatitis C infection in Thalassemic children. Pak Pediatr J 2003, 27:161-164.

12. Mirza IA, Mirza SH, Irfan S, Siddiqi R, Tariq WUZ, Janjua AS: Seroprevalence of hepatitis $B$ and $C$ in young adults seeking recruitment in armed forces. Pak Armed Forces Med J 2006, 56:192-197.

13. Sharif BT, Tariq WZ: Seroprevalence of hepatitis B and $C$ in healthy adult male recruits. Pak J Pathol 2006, 17:142-146. 
14. Ahmad N, Asgher M, Shafique M, Qureshi JA: An evidence of high prevalence of Hepatitis C virus in Faisalabad, Pakistan. Saudi Med J 2007, 28:390-395.

15. Platt L, Vickerman P, Collumbien M, Hasan S, Lalji N, Mayhew S, Muzaffar R, Andreasen A, Hawkes S: Prevalence of HIV, HCV and sexually transmitted infections among injecting drug users in Rawalpindi and Abbottabad, Pakistan: evidence for an emerging injection-related HIV epidemic. Sex Transm Infect 2009, 85(Suppl 2):ii17-ii22.

16. Muhammad N, Jan MA: Frequency of hepatitis " $C$ " in Buner, NWFP. J Coll Physicians Surg Pak 2005, 15:11-14.

17. Shahid JM, Ali H, Shaheen R, Basit A: Prevalence, Knowledge and Awareness of hepatitis $C$ among resident of three union council in Mansehra. J Ayub Med Coll Abbottobad 2010, 22(3):192-196.

18. World Health Organization: Hepatitis C factsheet. Available at: http://www. who.int/mediacentre/factsheets/fs164/en/index.html.

19. Raja NS, Janjua KA: Epidemiology of hepatitis C virus infection in Pakistan. J Microbiol Immunol Infect 2008, 41:4-8.

20. Shah NH, Shabbir G: A review of published literature on hepatits B \&C virus prevalence in Pakistan. J Coll Phys Surg Pakistan 2005, 15(5):257-260.

21. Khan A, Tareen AM, Ikram A, Rahman H, Wadood A, Qasim M, Khan K: Prevalence of HCV among the young male blood donors of Quetta region of Bolichistan, Pakistan. Virol J 2013, 10:83.

22. Shaikh F, Husain SQ, Naqvi Jilani NK, Rubina Memon RA: Prevalence and risk factors for Hepatitis C virus during pregnancy. Gomal J Med Sci 2009, 7:86-88.

23. Wazir MS, Mehmood S, Ahmed A, Jadoon HR: Awareness among barbers about health hazards associated with their profession. J Ayub Med Coll Abbottabad 2008, 20:35-38

24. Abdul Mujeeb S, Adil MM, Altaf A, Hutin Y, Luby S: Recycling of injection equipment in Pakistan. Infect Control Hosp Epidemiol 2003, 24(2):145-146.

25. Arshad A, Arshad M, Pervaiz R, Farzana Javed A, Ahmad ND, Ali I, Saljo AR: Prevalence of active hepatitis $C$ infection in the general population of district Mardan Khyber Pakhtoonkhawa, Pakistan. J Public Health Biol Sci 2012, 1(1):3-8

26. Ali A, Ahmad H, Ali I, Khan S, Zaidi G, Idrees M: Prevalence of active hepatitis C virus infection in district Mansehra, Pakistan. Virol J 2010, 7:334.

27. Ghany MG, Strader DB, Thomas DL, Seeff LB: Diagnosis, management, and treatment of hepatitis C: an update. Hepatology 2009, 49:1335-1374.

28. Chevaliez S: Virological tools to diagnose and monitor hepatitis $C$ virus infection. Clin Microbiol Infect 2011, 17(2):116-121.

29. Alter MJ, Kuhnert WL, Finelli L: Centers for Disease Control and Prevention. Guidelines for laboratory testing and result reporting of antibody to hepatitis C virus. Centers for Disease Control and Prevention. MMWR Recomm Rep 2003, 52:1-13.

30. CDC: Guidelines for laboratory testing and result reporting of antibody to hepatitis C virus. MMWR 2003, 52(RR-3):1-16.

31. Bukh J, Miller RH, Purcell RH: Genetic heterogeneity of hepatitis C virus: Quasispecies and Genotypes. Semin Liver Dis 1995, 15:41-63. immunoassay based detection and prevalence of HCV infection in district Peshawar Pakistan. Virology Journal 2014 11:127.

\section{Submit your next manuscript to BioMed Central and take full advantage of:}

- Convenient online submission

- Thorough peer review

- No space constraints or color figure charges

- Immediate publication on acceptance

- Inclusion in PubMed, CAS, Scopus and Google Scholar

- Research which is freely available for redistribution 